NBER WORKING PAPER SERIES

\title{
US MULTINATIONALS IN PUERTO RICO AND THE REPEAL OF SECTION 936 TAX EXEMPTION FOR U.S. CORPORATIONS
}

\author{
Zadia M. Feliciano \\ Andrew Green \\ Working Paper 23681 \\ http://www.nber.org/papers/w23681 \\ NATIONAL BUREAU OF ECONOMIC RESEARCH \\ 1050 Massachusetts Avenue \\ Cambridge, MA 02138 \\ August 2017
}

Thanks to Aaron Brezel for his excellent research assistance. Thanks to the members of the Lipsey Panel at the WEAI conference in Portland, OR, members of the Economics Seminar at Queens College, CUNY and Yokohama National University for useful comments. The views expressed herein are those of the authors and do not necessarily reflect the views of the National Bureau of Economic Research.

NBER working papers are circulated for discussion and comment purposes. They have not been peer-reviewed or been subject to the review by the NBER Board of Directors that accompanies official NBER publications.

(C) 2017 by Zadia M. Feliciano and Andrew Green. All rights reserved. Short sections of text, not to exceed two paragraphs, may be quoted without explicit permission provided that full credit, including $\odot$ notice, is given to the source. 
US Multinationals in Puerto Rico and the Repeal of Section 936 Tax Exemption for U.S. Corporations Zadia M. Feliciano and Andrew Green

NBER Working Paper No. 23681

August 2017

JEL No. F21,F23,H25

\begin{abstract}
$\underline{\text { ABSTRACT }}$
Puerto Rico, the Commonwealth Island and unincorporated territory of the United States, was placed under a fiscal Oversight Board by the U.S. Congress in 2016. Unable to pay $\$ 72$ billion it owes to bond holders, Puerto Rico's Government and the Oversight Board filed for court proceedings under Title III of the Puerto Rico Oversight, Management and Economic Stability Act, similar to Chapter 9 of the US Bankruptcy code. The origins of the crisis in Puerto Rico have been attributed in part to the phase out of the IRS Section 936 tax exemption program for U.S. corporations from 1995 to 2005 and its elimination in January 2006. Using industry panel data, compiled from the IRS Statistics of Income for U.S. Possessions Corporations, the U.S. Economic Census for Outlying Areas, and the mainland U.S. Economic Census, we analyze the effects of the phase out and elimination of Section 936 on the number of establishments, value added, employment, and wages in Puerto Rico's manufacturing. Our results show the elimination of Section 936 had the effect of decreasing average manufacturing wages by $16.7 \%$, and decreasing the number of manufacturing establishments by $18.7 \%$ to $28.0 \%$
\end{abstract}

Zadia M. Feliciano

NBER

5 Hanover Square, 16th Floor

Suite 1602

New York, NY 10004-2630

zadia.feliciano@qc.cuny.edu

Andrew Green

The Graduate Center, CUNY

365 Fifth Avenue

New York, NY 10016

agreen@gradcenter.cuny.edu 


\section{Puerto Rico and Section 936 of the IRS}

Puerto Rico, the Commonwealth Island and unincorporated territory of the United States, was placed under a Financial and Oversight Board by the U.S. Congress in 2016. Unable to pay for its 72 billion-dollar debt, the Puerto Rican Government and the Oversight Board, filed for court proceedings under Title III of the Puerto Rico Oversight Management and Economic Stability Act (PROMESA) in May 2017, similar to Chapter 9 of the U.S. Bankruptcy Code (Andrew Scurria, and Heather Gillers, WSJ May 4, 2017). The origins of the crisis in Puerto Rico have been attributed in part to the phase out of the IRS Section 936 tax exemption program for U.S. corporations from 1995 to 2005 and its elimination in January 2006. (Krueger, Teja and Wolfe, 2015). Despite this claim, there has been no econometric analysis of the impact of the phase out and elimination of Section 936 tax exemption program on economic conditions in Puerto Rico.

Using industry level panel data, compiled from Internal Revenue Service Statistics of Income for US Possessions Corporations, US Economic Census for Outlying Areas, and the mainland US Economic Census we analyze the effects of the phase out of Section 936 on the number of establishments, value added (sales or shipments), employment, and wages in Puerto Rico's manufacturing industries using data from 1982 to 2012. Difference in difference regression results show the elimination of the tax exemption program was associated with a $16.7 \%$ reduction in average manufacturing wages in Puerto Rico, when using the US as a control group. Additional regressions show eliminating the tax program may be responsible for an $18.7 \%$ to $28 \%$ decline in the number of manufacturing establishments, when using the states of Indiana, North Carolina and Oregon as the control group. These results suggest the elimination of Section 936 had a negative impact on economic conditions in Puerto Rico. 


\section{Section 936 of the IRS Tax Code}

In 1921, Federal income tax laws provided an incentive for U.S. corporations to conduct business in a U.S. possession territory such as Puerto Rico. The original legislation provided an exemption from taxation for all income derived from sources outside the United States if the corporation had derived 80 percent or more of its gross income from U.S. Possessions, and 50 percent or more of its gross income from the active conduct of trade or business in the U.S. Possession (Holik, 2009). ${ }^{1}$

The Tax Reform Act of 1976 changed the taxation of U.S. corporations operating in U.S. possessions, creating a new Section 936 of the Internal Revenue code. The new legislation allowed only a credit against taxes paid on income derived from the active conduct of trade or business in a U.S. possession and qualified possessions source investment income. The goal of this legislation was to encourage employment-producing investments in U.S. possessions by U.S. corporations (Holik, 2009).

The Tax Equity and Fiscal Responsibility Act of 1982 and the Tax Reform Act of 1986 further restricted tax benefits available under Section 936 by changing the tax treatment of income derived from intangible assets and passive investments. The 1982 Act provided that a possessions corporation's income from intangible assets, such as patents and copyrights, would be taxable to the U.S. shareholders (usually the U.S. parent corporation) of the possessions corporation. A possessions corporation could avoid this general rule if it demonstrated that it had a significant business presence in the possession by meeting a direct labor or value-added test with respect to a specific product or service produced. The percentage of gross income that a

\footnotetext{
${ }^{1}$ Unlike the foreign tax credit, the possessions tax credit could reduce and, in some cases, eliminate the U.S. tax liability on qualified possessions income whether or not the possessions tax that income.
} 
possessions corporation must earn from trade or business in U.S. possessions was originally set to 65 percent but increased to 75 percent in 1986 (Holik, 2009).

Tax exemption given to U.S. corporation in U.S. territories was phased out between 1995 and 2005. Transition rules allowed existing possessions corporation to claim credits, with certain restrictions, through taxable years beginning before January 1, 2006. The Act eliminated the credit for qualified possessions source investment income received or accrued after June 31, 1996. However, existing investors could continue to claim reduced credit amounts for active income using a percentage or economic activity limitation. The Small Business Job Protection Act of 1996 eliminated the Section 936 tax credit for tax years after December 31, 1995 (Holik, 2009).

Even though tax exemption through Section 936 applied to all U.S. possessions territories, U.S. possessions corporations with operations in Puerto Rico accounted for virtually all of the possessions tax credits. ${ }^{2}$ In $2005,98.8 \%$ of the 0.9 billion dollars in tax credits claimed were from US possessions corporations located in Puerto Rico. Moreover, of the 102 possessions corporations claiming credit, 94 were located in Puerto Rico. These corporations also accounted for nearly all of the assets, receipts, and net income of corporations claiming the credit. Most of the tax credit was given to manufacturing firms accounting for $69 \%$ of possessions tax credit in 2005 (Holik, 2009).

\footnotetext{
2 U.S. possessions include Puerto Rico, Guam, American Samoa, the Commonwealth of the Northern Mariana Islands, and the U.S. Virgin Islands.
} 


\section{Literature on Taxation, Firm Location and US Corporations}

The literature on Taxation and FDI is extensive. Theoretical models of the impact of taxes on the location of FDI consider whether firms engage in horizontal FDI, which has the goal of establishing production abroad to serve local labor markets, or vertical FDI, which involves locating different stages of production in different countries depending on relative factor endowments (Fuest et al, 2005, Helpman, 1984, 1985, Horstmann and Markusen, 1992). Some empirical studies use these theoretical models to estimate tax semi elasticities of FDI (Devereux and Lockwood, 2006, Devereux et al, 2015) while others use gravity models (Bellakk et al, 2009).

Feld and Heckemeyer (2011) conducted a meta study of FDI and taxation. They reviewed 704 primary estimates of the tax semi elasticities of FDI and found the precision weighted average elasticity is -2.55 , and when publication selection was taken into count the elasticity decreases to between -2.28 and -1.19 . This suggests firm location is very sensitive to tax levels and thus the elimination of tax exemption for U.S. corporations in Puerto Rico may have had large impact on the decision of firms to continue operating in the territory or leaving the island for other less costly locations.

In a tax study, Hexner and Jenkins (1995) found that the job creating benefits of section 936 in Puerto Rico were not large enough to justify the U.S. loss in tax revenue. Possessions Corporations received full credit against U.S. taxes owed on the net income earned in a U.S. possession, regardless of whether the income was generated by the use of tangible property and labor, or intangible property transferred to the Possession's Corporation. They argued section 936 did not produce enough employment because it benefited capital-intensive firms such as pharmaceuticals and did not benefit labor-intensive industries such as apparel manufacturers. 
Section 936 was a costly tax benefit to a few corporations with limited benefits to possessions economies and their exports. Moreover, they argued the Section 936 tax code could not be fixed and thus had to be abolished (Hexner and Jenkins, 1995).

Previous research by Grubert and Slemrod (1998) investigated the Section 936 Possessions Corporations tax exemption program. They analyzed 419 Possessions Corporations firms in 1987 and found the operating capital and payroll of Puerto Rican affiliates would be more than two thirds lower in the absence of income shifting. They predicted that the elimination of tax exemption for Puerto Rico, would result in many firms leaving or reducing the size of their operations in the island.

\section{Data}

We constructed two different data sets to study the impact of the elimination of Section 936 tax exemption for U.S. corporations on value added, number of manufacturing establishments, average wages and employment in Puerto Rico. The first data set is based on the Internal Revenue Service Statistics of Income for U.S. Possessions Corporations. We constructed a panel of 23 2-digit Standard Industrial Classification (SIC) industries of US Possessions Corporations for the years 1993 to 2005 (see Appendix A for description of industries). These data include the last 12 years of tax exemption for U.S. corporations in Puerto Rico, including the ten-year phase out period that started in 1995. The panel includes data on number of tax returns filled by U.S. possessions corporations, value of tax credits, total expenditures on salaries and wages, net depreciating assets, net intangible assets, and business receipts.

The second data set is based on the U.S. Economic Census for Outlying Areas, and the mainland U.S. Economic Census. We constructed a panel of industries originally at the 2-digit 
SIC level from 1982 to 1992 and at the 3-digit North American Industrial Classification System (NAICS) level from 1997 to 2012 with some consolidation resulting in 14 industries. The panel includes data in five year intervals for years between 1982 and 2012 (See Appendix B for Description of Industries). ${ }^{3}$ These data were collected in five year intervals because the Economic Census is conducted every five years. Variables included in these data include value added (sales in the case of U.S. state data), number of manufacturing establishments, employment and payroll expenses.

We also constructed a data set based on a report by the Junta de Planificación of Puerto Rico "Impacto de las Firmas Manufactureras 936 sobre la Economía de Puerto Rico," which includes information on firms within industries receiving tax exemption through Section 936 and firms within industries not receiving tax exemption in 1987. These data are used for descriptive purposes.

\section{Methodology}

We estimated a fixed effects model to analyze the impact of the elimination of the Section 936 tax exemption program for U.S. corporations in Puerto Rico. Puerto Rico is a territory of the United States and has no votes in the U.S. Congress. The phase out of Section 936 was a policy change imposed on Puerto Rico by the U.S. Congress, driven by the desire to increase U.S. tax collection. For this reason, the policy is exogenous to economic conditions in the island and it is a natural experiment on the impact of removing tax exemptions on the location of US multinational corporations.

\footnotetext{
${ }^{3} \mathrm{We}$ created a concordance to reconcile 2-digit SIC and 3-digit NAICS industries. The U.S. Census classified data on and prior to 1997 by SIC and after 1997 by NAICS. The concordance is available in Appendix A. Mapping of 2-digit SIC into 3-digit NAICS required reducing the number of industries to 14.
} 
First, we document the relationship between the value of tax credits given to U.S. corporations in Puerto Rico, and the number of U.S. firms filing for tax credits. We also estimate the relationship between the value of tax credits given to U.S. Possessions Corporation in Puerto Rico and their expenditures on worker compensation. Our data on U.S. Possessions Corporations is biannual, starting in 1993 and ending in 2005.

We use a fixed effects model described by the following equation:

$\left.\log _{\left(\text {USFirms }_{i t}\right.}\right)=\alpha+\beta_{1}$ LTaxCredits $_{i t}+\beta_{2}$ LDepAssets $_{i t}+\beta_{3}$ LIntanAssets $_{i t}+$ $\beta_{4}$ LBusReceipts $_{i t}+\sum_{i}$ Ind $_{i}+\sum_{t}$ Year $_{t}+\varepsilon_{i t}$

Where USFirms is the number of U.S. possessions corporations filing for tax exemption in industry $\mathrm{i}$ and year $\mathrm{t}$. TaxCredit is the value of tax credits awarded to U.S. possessions corporations by the IRS. DepAssets, IntanAssets and BusReceipts represent respectively the value of depreciable assets, intangible assets and business receipts for U.S. possessions corporations. Ind is a group of industry dummy variables and Year is a group of year dummy variables. We estimate a similar regression using Total Worker Compensation as the dependent variable. All variables are in logs and all regressions are estimated using industry cluster standard errors.

We estimate a second regression equation to analyze the impact of the elimination of tax exemption for U.S. corporations in Puerto Rico using a difference in difference estimation method. The first difference is before (1982 to 1992), during the ten-year phase out period (from 1995 to 2005) and after the elimination of Section 936 (after 2005). The second difference measures the difference in the industry level trends for the same periods for Puerto Rico and a control group. 
It is difficult to find a perfect control group for Puerto Rico's manufacturing industries since Puerto Rico has significantly lower wages than all states in the U.S., its location is far from the mainland, and because it is an island and requires maritime and air transportation for all goods. For this reason, we estimate regressions using 3 alternative control groups. The first control group is the entire United States, which including all 50 states. The second and third control groups are made of states. One group of states includes Indiana, North Carolina and Oregon. Another group of states includes Indiana, North Carolina, Oregon and New Jersey. The reason Indiana and North Carolina were selected is that they have the largest manufacturing share of state GDP in the U.S. Oregon was selected because, like Puerto Rico, it has a large proportion of workers in food and beverages. New Jersey was selected because it has a large share of employment in chemical and allied products, mostly pharmaceuticals. Comparisons of manufacturing industries in Puerto Rico, Indiana, North Carolina, New Jersey and Oregon are shown in Appendix C.

We estimate the following difference in difference equation: $\log \left(\right.$ Establishments $\left._{i j t}\right)=\alpha+\beta_{1}$ TaxCreditPhaseOut $_{i j t}+\beta_{2}$ AfterTaxCredit $_{i j t}+$ $+\beta_{3} d P R_{j}+\beta_{4} d P R_{j} *$ TaxCreditPhaseOut $t_{i j t}+\beta_{5} d P R_{j} *$ AfterTaxCredit $_{i j t}+\sum_{i}$ Ind $_{i}+$ $\sum_{t}$ Year $_{t}+\varepsilon_{i j t}$ where Establishments is the number of manufacturing establishments in location $\mathrm{j}$ (PR or Control Group) industry i and time t. TaxCreditPhaseOut is a dummy variable that equals 1 if the year is during the ten-year phase out period of Section 936 (1995 to 2005) and 0 otherwise. AfterTaxCredit is a dummy variable that equals 1 if the year is after the elimination of the Section 936 tax exemption program (after 2005). The interaction terms between the PhaseOut and AfterTaxCredit variables and the Puerto Rico dummy variable capture the differences 
between Puerto Rico and the control group during the phase out and elimination of the tax exemption program. These coefficients are the difference in difference estimators and thus capture the impact of the phase out and elimination of the Section 936 tax exemption program in Puerto Rico.

We estimate similar difference in difference regression equations using value added (sales or shipments)), employment and average wages as the dependent variable. ${ }^{4}$ All dependent variables are in logs. All variables are measured in 5-year intervals. All regressions are estimated using industry location cluster standard errors to account for correlation within industries within a location. When the U.S. is the control group, we use industry-PR and Industry-US specific standard errors. When the control group is a group of states, we use

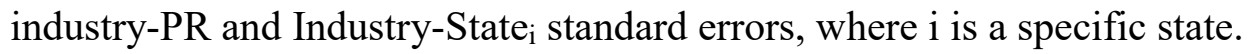

\section{Description and Trends for Section 936 Corporations}

Figure 1 shows tax credits given to U.S. corporations operating in U.S. territories from 1983 to 2005. Tax credits awarded to U.S. possessions corporations increased from 1983 to 1993, and declined continuously from 1995 to 2005 . The decline in tax credits can be attributed to the ten-year phase out of Section 936 tax exemption program starting in 1995 and its elimination on January 2006. In contrast, the number of US Corporations applying for Section 936 tax credits declined from 1983 to 2005. This suggests some of the trends in the number of U.S. possessions corporations is unrelated to the tax exemption program.

\footnotetext{
${ }^{4}$ The mainland U.S. Economic Census provides information on value added at the national level but only sales and value of shipments at the state level. The U.S. Economic Census for Outlying Areas includes both value added, and sales or shipments. For this reason, we use value added as the dependent variable when the control group is the United States, and sales or shipments when the control group is a group of states.
} 
Figure 2 shows manufacturing figures for Puerto Rico from 1982 to 2012 using data from the U.S. Economic Census for Outlying Areas. This graph shows a different trend for manufacturing establishments than the one shown in Figure 1. The number of manufacturing establishments in Puerto Rico gradually declined from 1982 to 1997, increased from 1997 to 2002, and sharply declined after 20002. In contrast to the establishment statistics, employment in manufacturing continuously increased from 1982 to 1997 and experienced a sharp declined after 1997. The decline in employment coincides with the ten-year phase out and elimination of the Section 936 tax credit. These statistics suggests that some of the decline in manufacturing in Puerto Rico maybe due to the ten-year phase out and ultimate elimination of Section 936.

Table 1 shows industry level statistics for U.S. possessions corporations operating under Section 936 from the IRS Statistics of Income for US Possessions Corporation for 1993. These statistics show four industries received most of the tax credits: food and kindred products (12.6\%), chemical and allied products (49.9\%), electrical and electronic equipment $(22.5 \%)$, and instruments and related products $(9.5 \%)$. The Chemical and Allied products industry stands out as the largest industry group accounting for close to $50 \%$ of the Section 936 tax credits and approximately $24 \%$ of all tax returns of the program. Most industries in the Chemical and Allied products were in pharmaceuticals.

Table 2 shows the importance of U.S. possessions corporations in Puerto Rico's manufacturing industry using a report from the Junta de Planificación of Puerto Rico with statistics on firms filing under section 936 and firms not filing under section 936 for the year 1987. These data show U.S. possessions corporations filing under Section 936 accounted for $82.8 \%$ of manufacturing production in the island. Moreover, firms filing under section 936 accounted for over $90 \%$ of production in tobacco products, textile mills, chemical and allied 
products, petroleum and coal products, leather and leather products, industrial machinery, electronic and other equipment, and instruments and other products. Overall, these statistics show Section 936 firms accounted for most manufacturing conducted in Puerto Rico in 1987.

\section{Results}

Tables 3 shows estimates of the relationship between the number of U.S. corporations filing for tax credits under Section 936 and the value of tax credits granted by the IRS using data from Statistics of Income for US Possessions Corporations from 1983 to 2005. The dependent variable is the number of U.S. corporations filing for Section 936 tax credits and the independent variable is the value of tax credits given to US Corporations under Section 936. Regressions show that as the value of U.S. corporations tax credits increased within an industry, the number of US Corporations filing for tax credits increased. The coefficient on value of tax credits is significant at the 5 percent level.

It is difficult to establish a causality. An increase in the value of tax exemption given to U.S. corporations can attract additional U.S. corporations to do business in Puerto Rico and file under Section 936. At the same time, an increase in the number of U.S. corporations filing under Section 936 can increase the value of tax credits. The purpose of these regressions is to show that increasing Section 936 tax credits from 1983 to 1994 is associated with an increase in the number of U.S. corporations filing for tax credits and the decline in tax credits offered to U.S. corporations during the ten-year phase out of Section 936, from 1995 to 2005, was associated with a decline in the number of U.S. corporations filing for tax credits.

Regressions in Table 3 also show there is no clear relationship between the value of tax credits received by U.S. corporations and their expenditures on salaries and wages. Regressions 
of expenditures on salaries and wages (dependent variable) on tax credits and financial characteristics of firms show the coefficients on value of tax credits is statistically insignificant and thus we cannot reject the possibility it is equal to zero. This validates some of the criticism of the Section 936 tax exemption program since firms that received larger tax credits did not have higher expenditures on workers. The only variable significantly related to expenditures on salaries and wages is business receipts, the coefficient is positive and statistically significant at the $5 \%$ level.

Table 4 shows the difference in difference estimates of the impact of Section 936 on the number of manufacturing establishments, value added (sales or shipments)), employment and average wages of workers in manufacturing industries using the U.S. (all 50 states) as the control group. The difference in difference coefficients are captured by the interaction terms between the Puerto Rico dummy variable and the dummy variable for the ten-year phase out period of Section 936, and between the Puerto Rico dummy variable and the years after the elimination of Section 936. These coefficients show differences between industries in Puerto Rico and the United States during the years Section 936 was phased out and eliminated. The results show no significant impact of the elimination of Section 936 on the log number of establishments, value added, and employment in Puerto Rico (columns 1, 2 and 3). Coefficients on the interaction terms are insignificant. Coefficients on tax credit phase out, end of tax credit and the Puerto Rico dummy variables are all significant. However, we find a significant effect of the elimination on Section 936 on average wages (column 4) in Puerto Rico, the coefficient on the interaction term between the Puerto Rico dummy variable and the end of Section 936 tax credit dummy variable is significant at the $10 \%$ level. The estimated coefficient is -.167 and shows average 
manufacturing wages in Puerto Rico declined by approximately $16.7 \%$ relative to manufacturing wages in the U.S.

Table 5 shows estimates of the impact of the phase out and elimination of Section 936 on the log number of manufacturing establishments, value of sales or shipments, employment and average wages of workers using the states of Indiana, North Carolina and Oregon as controls. Results show no impact of the elimination of Section 936 on sales or shipments, employment and average wages in Puerto Rico (columns 2, 3 and 4). However, estimates show a significant impact of Section 936 on the number of manufacturing establishments (column 1). The coefficient on the interaction term between the Puerto Rico dummy variable and the dummy variable for the ten-year phase out period of Section 936 , is significant at the $10 \%$ level and is estimated at -.186. The coefficient on the interaction term between the Puerto Rico dummy variable and the years after the elimination of Section 936 is significant at the $10 \%$ level and is estimated at -.280 . This suggests the elimination of Section 936 may be responsible for an $18.7 \%$ to $28.0 \%$ reduction in the number of manufacturing establishments in Puerto Rico.

Table 6 shows estimates of the impact of the phase out and elimination of Section 936 on the log numbers of manufacturing establishments, value of sales or shipments, employment and average wages of workers using the states of Indiana, North Carolina, Oregon and New Jersey as controls. New Jersey was added to the control group because it has one of the largest concentrations of pharmaceuticals in the United States. Our regression estimates including New Jersey in the control group show no impact of the elimination of Section 936 on the number of manufacturing establishments, sales or shipments, employment and average wages in Puerto Rico. All coefficients on the interaction terms are insignificant (columns 1, 2, 3, 4). This suggests that our results are sensitive to the states included in the control group. Is the group of 
states that include New Jersey an appropriate control group for Puerto Rico? The answer is not clear but we believe New Jersey is not a perfect comparison state for Puerto Rico. Manufacturing wages in Puerto Rico were approximately 48\% lower than those in New Jersey in 1987 (see Appendix C). Thus, despite its large concentration of pharmaceutical firms it may not be the best control for manufacturing industry trends in the island.

\section{Conclusions}

After decades of offering tax exemption programs for U.S. corporations located in Puerto Rico, Congress phased out the IRS Section 936 tax exemption program from 1995 to 2005, and completely eliminated it by January 2006. Theoretical models and empirical studies of the impact of taxes on FDI predict the elimination of tax credits should have reduced the number of U.S. corporations located in Puerto Rico. Prior to this research, there has been no econometric analysis of the impact of the phase out of IRS Section 936 on the manufacturing industry in Puerto Rico.

Using industry panel data, compiled from the IRS Statistics of Income for U.S. Possessions Corporations, the U.S. Economic Census for Outlying Areas, and the mainland U.S. Economic Census, we analyze the effects of the phase out and elimination of Section 936 on the number of establishments, value added (sales or shipments), employments and wages using a difference in difference methodology. Regression results show the elimination of Section 936 had a negative impact on average manufacturing wages in Puerto Rico when using the U.S. as a control group. We estimated manufacturing wages in Puerto Rico declined by $16.7 \%$ due to the elimination of the tax exemption program. We also estimate the elimination of Section 936 may be responsible for an $18.7 \%$ to $28.0 \%$ reduction in the number of manufacturing establishments 
in Puerto Rico, when using Indiana, North Carolina, and Oregon as the control group. These results are sensitive to the inclusion of states in the control group. However, there are no perfect control groups for Puerto Rico because on average in 1987 manufacturing wages in the island were $53 \%$ lower than in the mainland U.S. Thus, we believe our estimates are a lower bound of the true effect of the elimination of tax exemption in Puerto Rico as, other things equal, the island should have not experienced as large a decline in manufacturing as the rest of the U.S.

How could the elimination of the Section 936 tax exemption program affect the number of establishments and average wages but not the number of manufacturing workers. Our data shows Puerto Rico experienced a decline in manufacturing jobs from 1995 to 2012. This also occurred in the control groups: U.S. (all states), Indiana, North Carolina, Oregon and New Jersey. The jobs that Section 936 created in Puerto Rico were in high paying industries: pharmaceuticals, medical devices and electronic equipment. The reduction of these types of jobs had the effect of decreasing average manufacturing wages in Puerto Rico. Our research suggests the phase out and elimination of the Section 936 tax exemption program contributed to the economic deterioration of the manufacturing industry in Puerto Rico. 


\section{Bibliography}

Bellak, C., Leibrecht, M. and Damijan, J.P. (2009), "Infrastructure endowment and corporate income taxes as determinants of foreign direct investment in Central and Eastern European countries," The World Economy 32: 267-290.

Devereux, Michael P., Clemens Fuest, and Ben Lockwood. (2015), “The Taxation of Foreign Profits: A Unified View”, Journal of Public Economics, v. 125, pp. 83-97.

Devereux, M.P. and Lockwood, B. (2006), "Taxes and the size of the foreign-owned capital stock: which tax rate matters?" Paper presented at the European Tax Policy Forum 2006, London.

Feld, Lars P., and Jost Henrich Heckemeyer. (2011), "FDI and Taxation: A Meta-Study." Journal of Economic Surveys, April 2011, v. 25, iss. 2, pp. 233-72

Fuest, C., Huber, B. and Mintz, J. (2005), "Capital mobility and tax competition.” Foundations and Trends in Microeconomics 1: 1-62.

Grubert, Harry and Joel Slemrod (1998), “The Effect of Taxes on Investment and Income Shifting to Puerto Rico," The Review of Economics and Statistics, Vol. 80, No. 3 (Aug., 1998), pp. 365-373.

Helpman, E. (1984), "A simple theory of international trade with multinational corporations," Journal of Political Economy 92: 451-471.

Helpman, E. (1985), "Multinational corporations and trade structure.” Review of Economic Studies 52: 443-458.

Hexner, Thomas J and Glenn P. Jenkins (1995), "Puerto Rico and Section 936: A Costly Dependence.” Tax Notes International, January 16, pp. 235-254.

Holik, Daniel S. (2009) “US Possessions Corporations, 2005.” Statistics of Income Bulletin, Vol Spring, pp. 92-105.

Horstmann, I.J. and Markusen, J.R. (1992), "Endogenous market structures in international trade," Journal of International Economics 32: 109-129.

Krueger, Anne O., Ranjit Teja and Andrew Wolf (2015), "Puerto Rico - A Way Forward," report for the Commonwealth of Puerto Rico and the Government Development Bank of Puerto Rico, June 29th, 2015.

Puerto Rico, Junta de Planificación (1993), "Impacto de las Firmas Manufactureras 936 sobre la Economía de Puerto Rico: Un ánalisis usando la técnica de Insumo-Prodcuto.”, Oficina del Gobernador, Estado Libre Associated de Puerto Rico. 
Scurria, Andrew and Heather Gillers. (2017), "Puerto Rico to Square Off with Creditors," Wall Street Journal, May 4.

United States Internal Revenue Service, Statistics of Income for US Possessions Corporations, 1993-2005. 


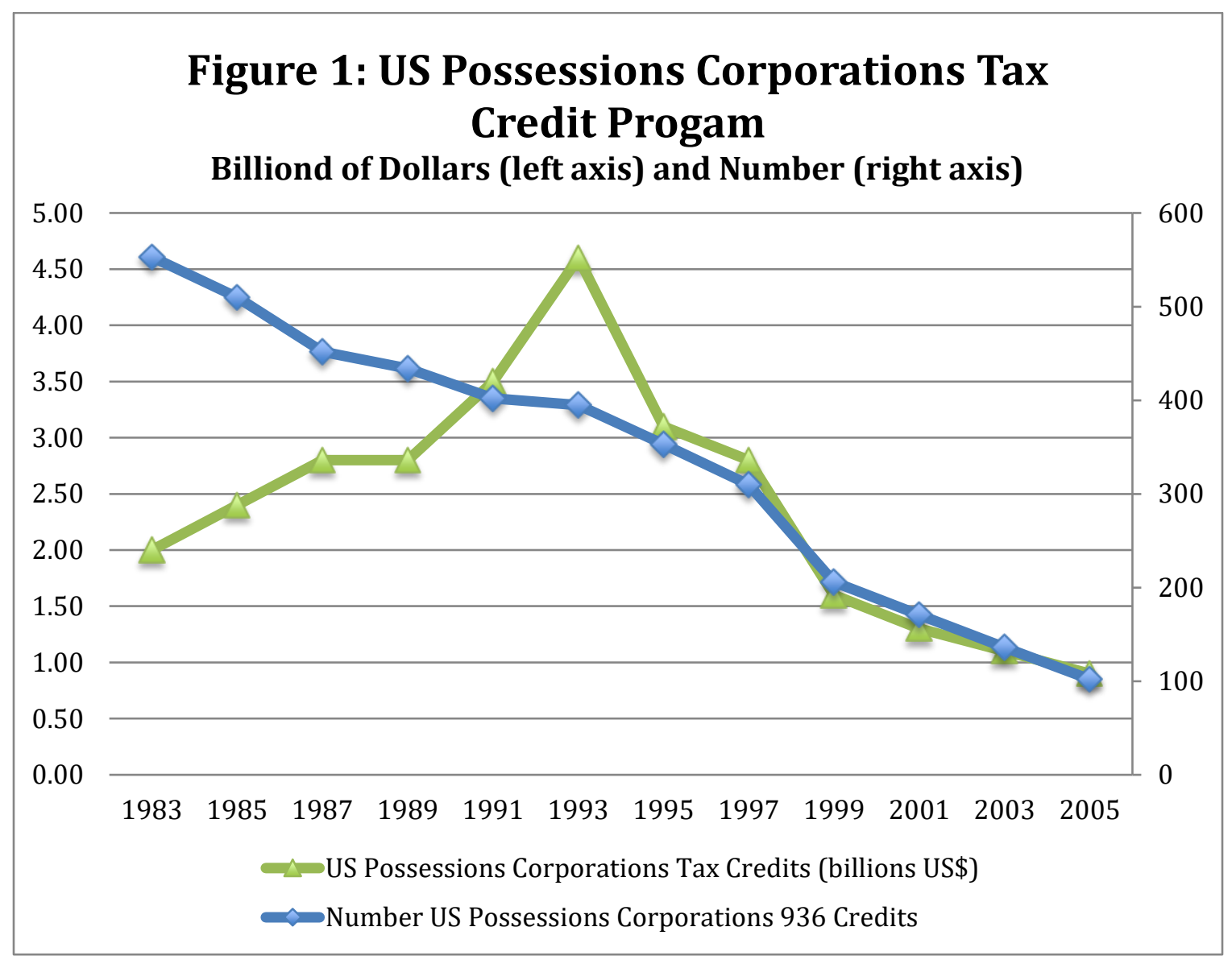

U.S. Posessions territories include Puerto Rico, Guam, American Samoa, Northern Mariana Islands and US Virgin Islands.

Source: US Possessions Corporations, Statistics of Income, US Internal Revenue Service, 2005. 


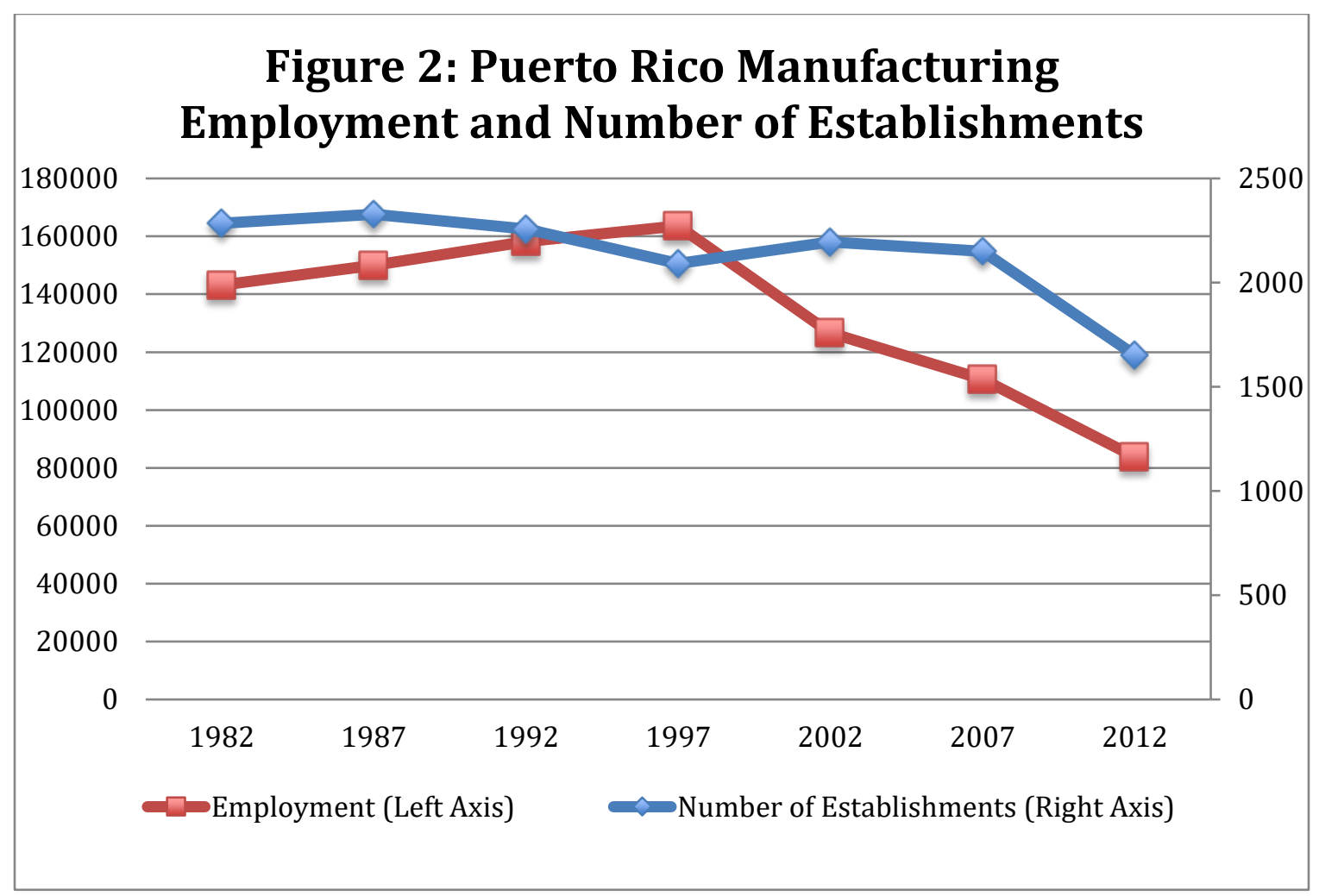

Source: U.S. Economic Census of Outlaying Areas. 
Table 1: U.S. possessions corporations, 1993

\begin{tabular}{|l|c|c|c|}
\hline & $\begin{array}{l}\text { Number of } \\
\text { 936 returns }\end{array}$ & $\begin{array}{l}\text { Percent of } \\
\text { 936 returns }\end{array}$ & $\begin{array}{l}\text { Percent of } \\
\text { 936 Tax } \\
\text { Credits }\end{array}$ \\
\hline Manufacturing Totals & 368 & & \\
\hline Food and kindred products & 27 & 7.34 & 12.58 \\
\hline Textile mill products & 5 & 1.36 & 0.02 \\
\hline Apparels and other textile products & 49 & 13.32 & 1.73 \\
\hline Paper and allied products & 10 & 2.72 & 0.10 \\
\hline Printing and publishing & 10 & 2.72 & 0.14 \\
\hline Chemicals and allied products & 88 & 23.91 & 49.85 \\
\hline Petroleum and Coal Products & 4 & 1.09 & 0.27 \\
\hline Rubber and Miscellaneous Products & 16 & 4.35 & 0.18 \\
\hline Leather and leather products & 13 & 3.53 & 0.46 \\
\hline Stone, clay, and glass products & 4 & 1.09 & 0.08 \\
\hline Fabricated metal products & 19 & 5.16 & 0.12 \\
\hline Machinery, except electrical & 10 & 2.72 & 1.04 \\
\hline Electrical and electronic equipment & 46 & 12.50 & 22.48 \\
\hline Transportation equipment & 4 & 1.09 & 0.29 \\
\hline Instruments and related products & 41 & 11.14 & 9.50 \\
\hline Miscellaneous manufacturing & 22 & 5.98 & 1.15 \\
\hline Not
\end{tabular}

Note: Includes Puerto Rico, Guam, American Samoa, Northern Mariana Islands and the U.S. Virgin Islands. Money amounts are in thousands of dollars Source: Statistics of Income, US Possessions Corporations, Internal Revenue Service. 
Table 2: Percent of manufacturing production in Section 936 U.S. possessions corporations in Puerto Rico, 1987.

\begin{tabular}{|c|l|c|}
\hline $\begin{array}{c}\text { SIC } \\
\text { Code }\end{array}$ & \multicolumn{1}{|c|}{ Industry Description } & $\begin{array}{c}\text { Production } \\
\text { by 936 firms } \\
\text { within Industry (\%) }\end{array}$ \\
\hline 20 & Food and kindred products & 72.6 \\
\hline 21 & Tobacco products & 99.3 \\
\hline 22 & Textile mill products & 91.0 \\
\hline 23 & Apparel and other textile products & 77.6 \\
\hline 24 & Lumber and wood products & 3.4 \\
\hline 25 & Furniture and fixtures & 3.4 \\
\hline 26 & Paper and allied products & 44.8 \\
\hline 27 & Printing and publishing & 9.0 \\
\hline 28 & Chemicals and allied products & 99.6 \\
\hline 29 & Petroleum and coal products & 94.6 \\
\hline 30 & Rubber and miscellaneous & 70.4 \\
\hline 31 & Leather and leather products & 93.6 \\
\hline 32 & Stone, clay, and glass & 11.8 \\
\hline 33 & Primary metal industrial products & 83.0 \\
\hline 34 & Fabricated metal products & 32.2 \\
\hline 35 & Industrial machinery & 97.8 \\
\hline 36 & Electronic and other & 96.2 \\
\hline 37 & Transportation equipment & 84.7 \\
\hline 38 & Instruments and related & 96.9 \\
\hline 39 & Miscellaneous manufacturing & 87.5 \\
\hline & All Manufacturing industries & 82.8 \\
\hline
\end{tabular}

Source: Junta de Planificación de Puerto Rico, 1993 
Table 3: Determinants of number of U.S. corporations claiming Section 936 tax credits and expenditures on salaries and wages, 1993-2005

\begin{tabular}{|c|c|c|c|c|}
\hline \multirow{2}{*}{$\begin{array}{l}\text { Independent Variables } \\
\text { Log Value US Corporations Tax Credits }\end{array}$} & \multicolumn{2}{|c|}{$\begin{array}{c}\text { Log } \\
\text { Number } \\
\text { US Corporations } \\
\text { Filing for Tax Credits }\end{array}$} & \multicolumn{2}{|c|}{$\begin{array}{c}\text { Log } \\
\text { Total } \\
\text { Expenditures on } \\
\text { Salaries and Wages }\end{array}$} \\
\hline & $\begin{array}{c}.200 \\
(.085)\end{array}$ & ** & $\begin{array}{l}.121 \\
(.084)\end{array}$ & \\
\hline Log Net Depreciating Assets & $\begin{array}{c}.005 \\
(.090)\end{array}$ & & $\begin{array}{c}.216 \\
(.117)\end{array}$ & * \\
\hline Log Net Intangible Assets & $\begin{array}{c}.035 \\
(.021)\end{array}$ & & $\begin{array}{l}-.001 \\
(.027)\end{array}$ & \\
\hline Log Business Receipts & $\begin{array}{c}.094 \\
(.080)\end{array}$ & & $\begin{array}{c}.531 \\
(.116)\end{array}$ & ** \\
\hline Number of Industries & 23 & & 23 & \\
\hline Industry Dummy Variables & Yes & & Yes & \\
\hline Year Dummy Variables & Yes & & Yes & \\
\hline Observations & 136 & & 136 & \\
\hline R-Squared & .41 & & .41 & \\
\hline
\end{tabular}

Cluster standard errors. * Significant at the $10 \%$ level, ${ }^{* *}$ Significant at the $5 \%$ level Source Data: IRS Statistics of Income, US Possessions Corporations 
Table 4: Manufacturing in Puerto Rico before and after the elimination of tax exemption for U.S. corporations, U.S. as control group.

\begin{tabular}{|c|c|c|c|c|c|c|c|c|}
\hline \multirow{2}{*}{$\begin{array}{l}\text { Independent } \\
\text { Variables } \\
\text { Tax Credit Phase } \\
\text { out (1995-2005) }\end{array}$} & \multicolumn{2}{|c|}{$\begin{array}{c}\text { Log } \\
\text { Number of } \\
\text { Establishments }\end{array}$} & \multicolumn{2}{|c|}{$\begin{array}{l}\text { Log } \\
\text { Value } \\
\text { Added }\end{array}$} & \multicolumn{2}{|c|}{$\begin{array}{c}\text { Log } \\
\text { Employment }\end{array}$} & \multicolumn{2}{|c|}{$\begin{array}{l}\text { Log } \\
\text { Average } \\
\text { Wage }\end{array}$} \\
\hline & $\begin{array}{l}.002 \\
(.104)\end{array}$ & & $\begin{array}{l}.644 \\
(.263)\end{array}$ & ** & $\begin{array}{l}.050 \\
(.247)\end{array}$ & & $\begin{array}{l}.498 \\
(.059)\end{array}$ & ** \\
\hline $\begin{array}{l}\text { End of Tax Credit } \\
(2005-2012)\end{array}$ & $\begin{array}{l}.144 \\
(.123)\end{array}$ & & $\begin{array}{l}.788 \\
(.318)\end{array}$ & ** & $\begin{array}{l}-.263 \\
(.277)\end{array}$ & & $\begin{array}{l}.787 \\
(.061)\end{array}$ & ** \\
\hline Puerto Rico & $\begin{array}{r}-4.892 \\
(.146)\end{array}$ & ** & $\begin{array}{l}-4.819 \\
(.344)\end{array}$ & ** & $\begin{array}{l}-4.752 \\
(.289)\end{array}$ & ** & $\begin{array}{l}-.490 \\
(.055)\end{array}$ & *** \\
\hline $\begin{array}{l}\text { Puerto Rico x } \\
\text { Tax Credit Phase } \\
\text { out }\end{array}$ & $\begin{array}{c}-.079 \\
(.130)\end{array}$ & & $\begin{array}{l}-.091 \\
(.313)\end{array}$ & & $\begin{array}{l}-.108 \\
(.275)\end{array}$ & & $\begin{array}{l}-.074 \\
(.071)\end{array}$ & \\
\hline $\begin{array}{l}\text { Puerto Rico } \mathrm{x} \\
\text { End of Tax Credit }\end{array}$ & $\begin{array}{c}-.098 \\
(.186)\end{array}$ & & $\begin{array}{l}.333 \\
(.483)\end{array}$ & & $\begin{array}{l}.172 \\
(.345)\end{array}$ & & $\begin{array}{l}-.167 \\
(.093)\end{array}$ & * \\
\hline Industries & 14 & & 14 & & 14 & & 14 & \\
\hline $\begin{array}{l}\text { Industry Dummy } \\
\text { Variables }\end{array}$ & Yes & & Yes & & Yes & & Yes & \\
\hline $\begin{array}{l}\text { Year Dummy } \\
\text { Variable }\end{array}$ & Yes & & Yes & & Yes & & Yes & \\
\hline Observations & 196 & & 191 & & 192 & & 192 & \\
\hline R-Squared & .98 & & .88 & & .91 & & .80 & \\
\hline
\end{tabular}

Clustered standard errors. * Significant at the $10 \%$ level, ${ }^{* *}$ Significant at the $5 \%$ level Source Data: U.S. Economic Census, and U.S. Economic Census of Outlaying Areas. 
Table 5: Manufacturing in Puerto Rico before and after the elimination of tax exemption for U.S. corporations, with Indiana, North Carolina, and Oregon as control group.

\begin{tabular}{|c|c|c|c|c|c|c|c|c|}
\hline \multirow{2}{*}{\begin{tabular}{|l|}
$\begin{array}{l}\text { Independent } \\
\text { Variables }\end{array}$ \\
$\begin{array}{l}\text { Tax Credit Phase } \\
\text { out (1995-2005) }\end{array}$
\end{tabular}} & \multicolumn{2}{|c|}{$\begin{array}{c}\text { Log } \\
\text { Number of } \\
\text { Establishments }\end{array}$} & \multicolumn{2}{|c|}{$\begin{array}{c}\text { Log } \\
\text { Sales or } \\
\text { Shipments }\end{array}$} & \multicolumn{2}{|c|}{$\begin{array}{c}\text { Log } \\
\text { Employment }\end{array}$} & \multicolumn{2}{|c|}{$\begin{array}{c}\text { Log } \\
\text { Average } \\
\text { Wage }\end{array}$} \\
\hline & $\begin{array}{l}.108 \\
(.066)\end{array}$ & & $\begin{array}{l}.536 \\
(.076)\end{array}$ & $* *$ & $\begin{array}{l}.001 \\
(.067)\end{array}$ & & $\begin{array}{l}.433 \\
(.012)\end{array}$ & $* *$ \\
\hline $\begin{array}{l}\text { End of Tax Credit } \\
(2005-2012)\end{array}$ & $\begin{array}{l}.038 \\
(.080)\end{array}$ & & $\begin{array}{l}.755 \\
(.113)\end{array}$ & ** & $\begin{array}{l}-.248 \\
(.099)\end{array}$ & $* *$ & $\begin{array}{l}.695 \\
(.020)\end{array}$ & $* *$ \\
\hline Puerto Rico & $\begin{array}{l}-1.27 \\
(.188)\end{array}$ & ** & $\begin{array}{l}-1.606 \\
(.388)\end{array}$ & ** & $\begin{array}{l}-1.477 \\
(.348)\end{array}$ & ** & $\begin{array}{l}-.457 \\
(.049)\end{array}$ & $* *$ \\
\hline $\begin{array}{l}\text { Puerto Rico x } \\
\text { Tax Credit Phase } \\
\text { out }\end{array}$ & $\begin{array}{l}-.186 \\
(.100)\end{array}$ & $*$ & $\begin{array}{l}-.159 \\
(.170)\end{array}$ & & $\begin{array}{l}-.047 \\
(.138)\end{array}$ & & $\begin{array}{l}-.004 \\
(.043)\end{array}$ & \\
\hline $\begin{array}{l}\text { Puerto Rico } \mathrm{x} \\
\text { End of Tax Credit }\end{array}$ & $\begin{array}{l}-.280 \\
(.157)\end{array}$ & * & $\begin{array}{l}-.433 \\
(.343)\end{array}$ & & $\begin{array}{l}-.211 \\
(.225)\end{array}$ & & $\begin{array}{l}.080 \\
(.069)\end{array}$ & \\
\hline Industries & 14 & & 14 & & 14 & & 14 & \\
\hline $\begin{array}{l}\text { Industry Dummy } \\
\text { Variables }\end{array}$ & Yes & & Yes & & Yes & & Yes & \\
\hline $\begin{array}{l}\text { Year Dummy } \\
\text { Variables }\end{array}$ & Yes & & Yes & & Yes & & Yes & \\
\hline Observations & 392 & & 379 & & 379 & & 378 & \\
\hline R-Squared & .87 & & .67 & & .71 & & .80 & \\
\hline
\end{tabular}

Clustered standard errors. * Significant at the $10 \%$ level, ${ }^{* *}$ Significant at the $5 \%$ level Source Data: U.S. Economic Census, and U.S. Economic Census of Outlaying Areas. 
Table 6: Manufacturing in Puerto Rico before and after elimination of tax exemption for U.S. corporations, with Indiana, North Carolina, New Jersey and Oregon as control group.

\begin{tabular}{|c|c|c|c|c|c|c|c|c|}
\hline \multirow{2}{*}{\begin{tabular}{|l|}
$\begin{array}{l}\text { Independent } \\
\text { Variables }\end{array}$ \\
$\begin{array}{l}\text { Tax Credit Phase } \\
\text { out (1995-2005) }\end{array}$ \\
\end{tabular}} & \multicolumn{2}{|c|}{$\begin{array}{c}\text { Log } \\
\text { Number of } \\
\text { Establishments }\end{array}$} & \multicolumn{2}{|c|}{$\begin{array}{c}\text { Log } \\
\text { Sales or } \\
\text { Shipments }\end{array}$} & \multicolumn{2}{|c|}{$\begin{array}{c}\text { Log } \\
\text { Employment }\end{array}$} & \multicolumn{2}{|c|}{$\begin{array}{c}\text { Log } \\
\text { Average } \\
\text { Wage }\end{array}$} \\
\hline & $\begin{array}{c}.033 \\
(.060)\end{array}$ & & $\begin{array}{l}.430 \\
(.065)\end{array}$ & ** & $\begin{array}{l}-.096 \\
(.059)\end{array}$ & & $\begin{array}{c}.349 \\
(.059)\end{array}$ & ** \\
\hline $\begin{array}{l}\text { End of Tax Credit } \\
(2005-2012)\end{array}$ & $\begin{array}{l}.088 \\
(.076)\end{array}$ & & $\begin{array}{l}.617 \\
(.102)\end{array}$ & $* *$ & $\begin{array}{l}-.367 \\
(.086)\end{array}$ & $* *$ & $\begin{array}{l}.333 \\
(.093)\end{array}$ & $* *$ \\
\hline Puerto Rico & $\begin{array}{l}-1.328 \\
(.183)\end{array}$ & ** & $\begin{array}{l}-1.682 \\
(.380)\end{array}$ & ** & $\begin{array}{l}-1.547 \\
(.342)\end{array}$ & $* *$ & $\begin{array}{l}-2.000 \\
(.368)\end{array}$ & $* *$ \\
\hline $\begin{array}{l}\text { Puerto Rico } x \\
\text { Tax Credit Phase } \\
\text { out }\end{array}$ & $\begin{array}{l}-.110 \\
(.096)\end{array}$ & & $\begin{array}{c}-.064 \\
(.164)\end{array}$ & & $\begin{array}{l}.042 \\
(.132)\end{array}$ & & $\begin{array}{l}.027 \\
(.130)\end{array}$ & \\
\hline $\begin{array}{l}\text { Puerto Rico x } \\
\text { End of Tax Credit }\end{array}$ & $\begin{array}{l}-.154 \\
(.154)\end{array}$ & & $\begin{array}{l}-.295 \\
(.338)\end{array}$ & & $\begin{array}{l}-.086 \\
(.220)\end{array}$ & & $\begin{array}{l}-.172 \\
(.255)\end{array}$ & \\
\hline Industries & 14 & & 14 & & 14 & & 14 & \\
\hline $\begin{array}{l}\text { Industry Dummy } \\
\text { Variables }\end{array}$ & Yes & & Yes & & Yes & & Yes & \\
\hline $\begin{array}{l}\text { Year Dummy } \\
\text { Variables }\end{array}$ & Yes & & Yes & & Yes & & Yes & \\
\hline Observations & 490 & & 473 & & 473 & & 472 & \\
\hline R-Squared & .87 & & .67 & & .70 & & .70 & \\
\hline
\end{tabular}

Clustered standard errors. * Significant at the $10 \%$ level, ${ }^{* *}$ Significant at the $5 \%$ level Source Data: U.S. Economic Census, and U.S. Economic Census of Outlaying Areas. 


\begin{tabular}{|l|c|}
\hline $\begin{array}{l}\text { Appendix A: } \\
\text { IRS industry classification of US possessions corporations }\end{array}$ & $\begin{array}{c}\text { SIC } \\
\text { Codes }\end{array}$ \\
\hline food and kindred products & 20 \\
\hline textile mill products & 22 \\
\hline textiles and apparel & 23 \\
\hline paper products & 26 \\
\hline printing & 27 \\
\hline chemical products & 28 \\
\hline petroleum and coal products & 29 \\
\hline plastics and rubber products & 30 \\
\hline leather and leather products & 31 \\
\hline nonmetallic mineral products & 32 \\
\hline primary and fabricated metals & 34 \\
\hline industrial machinery and equipment & 35 \\
\hline computers and electric equipment & 36 \\
\hline transportation equipment & 37 \\
\hline medical equipment and supplies & 38 \\
\hline miscellaneous manufacturing & 39 \\
\hline finance & $60-67$ \\
\hline agriculture, forestry, and fishing & $01-09$ \\
\hline construction & $15-17$ \\
\hline transportation and public utilities & 40 \\
\hline wholesale trade & $50-51$ \\
\hline retail trade & $52-59$ \\
\hline services & $70-89$ \\
\hline
\end{tabular}




\begin{tabular}{|c|l|c|c|}
\hline \multicolumn{2}{|c|}{ Appendix B: SIC to NAICS concordance } \\
\begin{tabular}{|c|l|c|} 
Industrial \\
Groups
\end{tabular} & \multicolumn{1}{c|}{ SIC } & NAICS \\
\hline 1 & Food, beverage and tobacco & 20,21 & 311,312 \\
\hline 2 & Textiles & 22,23 & $313,314,315$ \\
\hline 3 & Leather and leather products & 31 & 316 \\
\hline 4 & Lumber and wood products & 24 & 321 \\
\hline 5 & Paper and allied products & 26 & 322 \\
\hline 6 & Printing and publishing & 27 & 323 \\
\hline 7 & Petroleum and coal products & 29 & 324 \\
\hline 8 & Chemicals and allied products & 28 & 325 \\
\hline 9 & Rubber and misc. plastics products & 30 & 326 \\
\hline 10 & Stone, clay and glass products & 32 & 327 \\
\hline 11 & Primary metal industries & 33 & 331 \\
\hline 12 & Fabricated metal products & $34,35,36,37$, & $332,333,334,335$, \\
\hline 13 & Furniture and Fixtures & 25 & 336 \\
\hline 14 & Misc. manufacturing & 39 & 337 \\
\hline
\end{tabular}




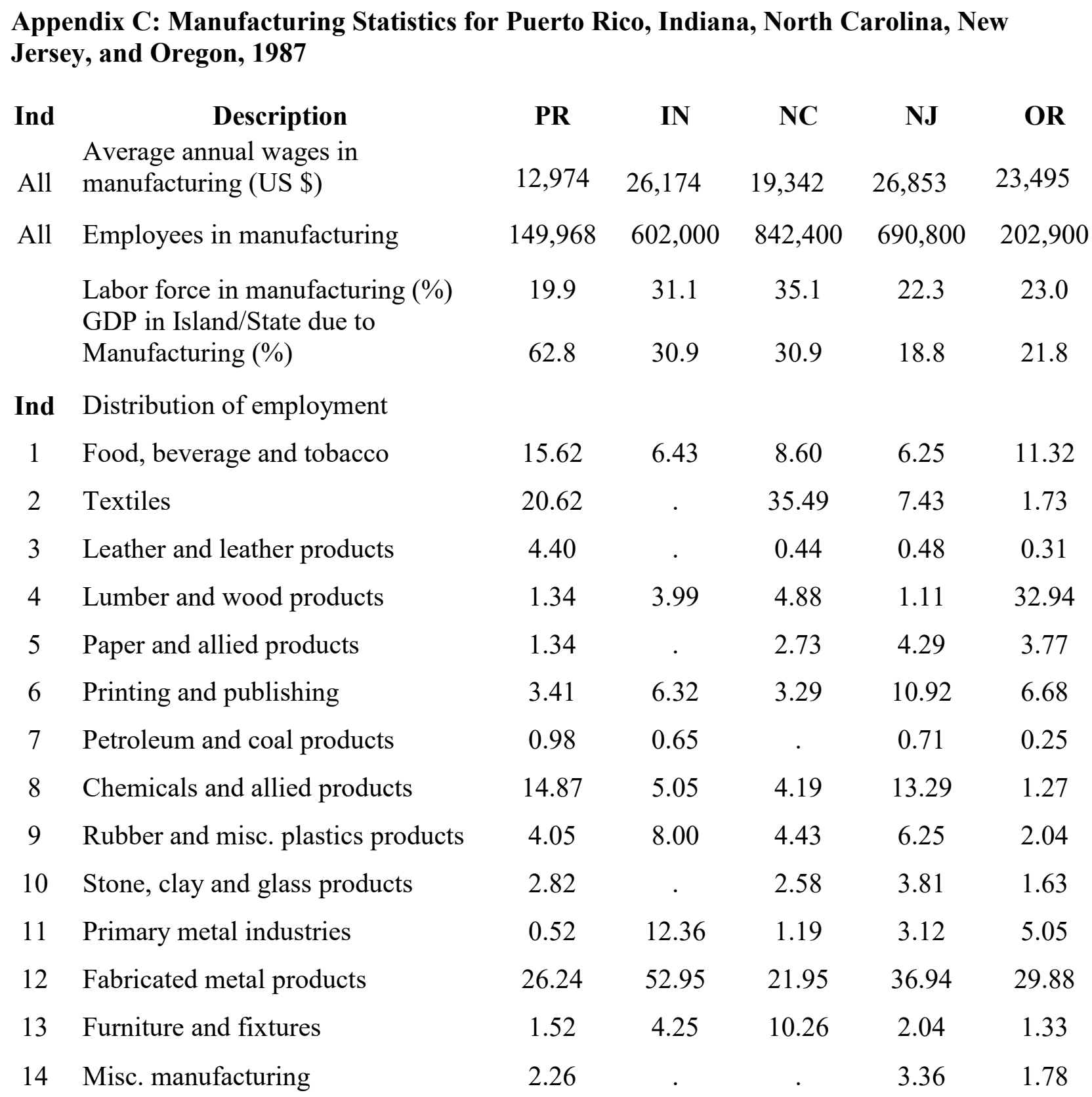

Source: U.S. Economic Census, and U.S. Economic Census of Outlaying Areas. 